\title{
PENINGKATAN MUTU UJIAN DARI PAPER BASED MENUJU COMPUTER BASED
}

\author{
Ferry Sudarto ${ }^{1}$ \\ Hidayati $^{2}$ \\ Ageng Setiani Rafika ${ }^{3}$ \\ e-mail:ferry.sudarto@faculty.raharja.ac.id,hidayati@faculty.raharja.ac.id, \\ agengsetiani@sk.raharja.ac.id.
}

Diterima : 19Desember 2011 / Disetujui : 28 Desember 2011

\begin{abstract}
Adoption of the exam objectives in a learning process is to determine the quality of one's learner after going through the learning process. Exams are also an evaluation of the monitoring process carried out continuously and sustainably will ultimately be able to fix the quality of education. Determination of the ever-increasing standards expected to encourage the improvement of education quality, which is the determination of educational standards is the determination of the limit value (passing score). Someone said to have passed / are competent when it has passed the limit value. In the world of Education in Higher Education Raharja for example, in order to obtain the concentration Communication and Innovative Technology (CCIT) who have exam system that $v$ used Cisco Certified Network Associate (CCNA) Benchmarking the learning standards. But it was not as easy as expected, due to problems regarding the exams are still using paper based are not in accordance with the standard CCNA Benchmarking using computer-based exam. Benchmarking standard exam is CCNA is a computer based exam where students can do the exam questions on a computer that random such questions, which makes each student can work on the problems at the same time but each working on different problems. In the matter of computer-based working time limits there are also questions it. In Higher Education Raharja, test is still manual (paper based) where the students are still working on the exam questions and answers contained in the paper. The concept paper based is much less effective,
\end{abstract}

1. Dosen Jurusan Sistem Komputer, STMIK Raharja

J1. Jend Sudirman No. 40 Modern Cikokol-Tangerang Telp. 5529692

2. Dosen Jurusan Sistem Informasi, STMIK Raharja

J1. Jend Sudirman No. 40 Modern Cikokol-Tangerang Telp. 5529692

3. Mahasiswa Jurusan Sistem Informasi, STMIK Raharja

J1. Jend Sudirman No. 40 Modern Cikokol-Tangerang Telp. 5529692

Vol.5 No.3 - Mei 2012 
can not even detect students who work together when the exam. At present it has developed a new method is more effective and certainly the most can help overcome these problems. Example for computer Based exam is CCNA exam and The Test of English as a Foreign Language (TOEFL) computer based and Raharja high-standard universities. In this article also identified at least four fundamental problems concerning the concept of computerbased exam, defining test methods based computer as a new way of tackling paper based exam, and final test of is to implement a computer based on the Higher Education Raharja. Computer-based methods is very important to be developed, because its function is effective in providing quality improvement exam in Higher Education Raharja thus continues to provide ease in doing the exam students and faculty in terms of giving value to students. In addition, computer-based exam process is also well suited to the needs. It can even be said that the computer based exams can erode the operational work of approximately $80 \%$ of original work not to perform the correction process answers all students who did a paper based exam.

Key Words: passing score, benchmarking cccna, ccit, toefl, computer based, paper based.

\section{ABSTRAKSI}

Tujuan diterapkannya ujian pada suatu proses pembelajaran adalah untuk mengetahui mutu seseorang pelajar setelah melewati proses pembelajaran. Ujian tersebut juga merupakan proses pemantauan evaluasi yang dilakukan secara terus menerus dan berkesinambungan pada akhirnya akan dapat membenahi mutu pendidikan. Penentuan standar yang terus meningkat diharapkan akan mendorong peningkatan mutu pendidikan, yang dimaksud dengan penentuan standar pendidikan adalah penentuan nilai batas (passing score). Seseorang dikatakan sudah lulus/kompeten bila telah melewati nilai batas. Di dunia Pendidikan pada Perguruan Tinggi Raharja misalnya, pada konsentrasi Creative Communication and Innovative Technology (CCIT) sistem ujiannya menggunakan sistem ujian berstandar Benchmarking Cisco Certified Network Associate (CCNA). Tapi ternyata tidak semudah yang diharapkan, karena masalah perihal ujian yang masih menggunakan paper based yang tidak sesuai dengan standar Benchmarking CCNA yang menggunakan ujian computer based. Ujian yang bertaraf benchmarking CCNA adalah merupakan ujian yang computer based dimana mahasiswa dapat mengerjakan soal-soal ujian pada komputer yang merandom soal-soal tersebut, yang menjadikan setiap mahasiswa dapat mengerjakan soal dalam waktu yang bersamaan tetapi masing-masing mengerjakan soal yang berbeda. Di dalam soal computer based juga terdapat batas waktu mengerjakan soal-soal tersebut. Ujian paper based yang manual dimana mahasiswa masih mengerjakan ujian yang soal dan jawabannya terdapat dalam kertas. Konsep paper based tersebut sangat kurang efektif, bahkan tidak dapat mendeteksi mahasiswa yang bekerja sama ketika ujian. Saat ini telah dikembangkan metode baru yang lebih efektif dan dipastikan secara maksimal dapat membantu mengatasi masalah-masalah tersebut. Metode tersebut dikenal dengan nama ujian computer based. Contoh dari ujian yang mengadopsi metode computer based selain ujian CCNA adalah ujian The Test of English as a Foreign Language (TOEFL) computer based. Dalam jurnal ini pun diidentifikasikan setidaknya ada empat masalah yang mendasar

Vol.5 No.3 - Mei 2012 
perihal konsep ujian paper based, mendefinisikan metode ujian computer based sebagai cara baru menanggulangi ujian paper based, dan terakhir yaitu mengimplementasikan ujian computer based pada Perguruan Tinggi Raharja. Metode ujian computer based ini sangat penting untuk dikembangkan, karena fungsinya yang efektif dalam memberikan peningkatan mutu ujian pada Perguruan Tinggi Raharja sehingga senantiasa memberikan kemudahan mahasiswa dalam mengerjakan ujian dan dosen dalam hal memberi nilai kepada mahasiswa. Selain itu, proses ujian computer based ini pun sangat sesuai dengan kebutuhan. Bahkan dapat dikatakan bahwa ujian computer based ini dapat mengikis pekerjaan pihak operasional kira-kira $80 \%$ dari pekerjaannya semula untuk tidak melakukan proses koreksi jawaban seluruh mahasiswa yang melakukan ujian secara paper based.

Kata Kunci: passing score, benchmarking ccna, ccit, toefl, computer based, paper based.

\section{PENDAHULUAN}

Proses ujian merupakan proses yang digunakan untuk mengukur penguasaan pelajar dalam sesuatu kegiatan belajar mengajar. Dalam konteks akademis atau profesional, ujian (atau ujian untuk pendek) adalah tes yang bertujuan untuk menentukan kemampuan seorang mahasiswa atau calon dokter. Biasanya ujian tes tertulis, walaupun beberapa mungkin praktis atau komponen praktis, dan sangat bervariasi dalam struktur [FJR09]. Ujian mengandung satu set soal-soal yang didalamnya berisi materi yang harus dikuasai dan kemudian dapat merangsang pelajar untuk menunjukkan tahap penguasaan mereka dalam suatu kegiatan belajar mengajar yang berkenaan. Tahap penguasaan pelajar biasanya dikuantifikasikan dengan memberi skor kepada jawaban yang diberi. Memandang ujian sebagai alat ukur yang sering digunakan untuk mendapatkan bukti empirik bagi tujuan penilaian pengajaran dan pembelajaran di universiti, maka mutu ujian itu sendiri harus diperbaiki seperti di dalam proses ujian itu sendiri, ujian harus benar-benar berlangsung secara nyaman, tertib dan tidak terdapat kecurangan. Serta tumpuan perlu diberi bagi membina ujian yang bermutu, dan mentafsir nilai hasil ujian dengan tepat. Tetapi, hal-hal tersebut belum terlalu dapat diimplementasikan di dalam proses ujian. [WKP11]

Upaya peningkatan mutu pendidikan pada Perguruan Tinggi Raharja telah dilakukan, baik melalui pengembangan mutu tenaga pengajar, penyelenggaraan pendidikan, serta pembangunan berbagai fasilitas penunjang proses pendidikan. Upaya-upaya tersebut ternyata belum menghasilkan perubahan secara nyata [KTM08]. Oleh karena itu masih perlu upaya dilakukannya pengembangan model pembelajaran dalam berbagai aspek setidaknya seperti pada ujian paper based yang sedang berlangsung saat ini ketika UTS dan UAS. 
UAS dan UTS pada pertengahan semester dan akhir semester merupakan salah satu kegiatan rutin yang dijalankan di lingkungan Perguruan Tinggi.Ujian tersebut merupakan kegiatan yang dilakukan seluruh mahasiswa aktif untuk menentukan nilai mata kuliah yang diambil pada semester tersebut. Prosesnya yang berlangsung di ruangan yang ditentukan dengan waktu dan soal yang juga sudah ditentukan. Dan, UTS dan UAS tersebut merupakan ujian paper based.

Tetapi, dalam ujian paper based menemukan banyak kesulitan, misalnya pada ujian CCIT paper based dan ujian The Test of English as a Foreign Language (TOEFL) Bahasa Inggris paper based. Karena standar ujian CCIT dan TOEFL yang ada pada Perguruan Tinggi Raharja mengadopsi standarisasi Internasional maka ujian paper based memicu banyaknya permasalahan. Pertama, dalam hal soal ujian, ujian ini tidak seperti ujian lainnya yang biasanya hanya 25-40 soal, banyaknya ujian berstandar Internasional dapat mencapai hingga 60 soal atau lebih serta pilihan jawaban yang lebih dari satu dan pilihan jawaban lebih dari 4 (empat) dapat sangat menyulitkan. Kedua, dalam hal mengerjakan ujian yang waktunya sangat kurang karena soalnya banyak serta berbahasa Inggris yang apabila membacanya memakan waktu yang cukup lama. Dan yang ketiga, untuk memeriksa hasil ujian pun mengalami kesulitan yang berarti karena membutuhkan waktu yang sangat lama untuk seorang dosen yang memeriksanya dan membutuhkan konsentrasi yang sangat tinggi dalam memeriksa hasil ujian mahasiswa.

\section{PERMASALAHAN}

Sepintas mungkin metode ujian paper based merupakan suatu dasar proses pengambilan nilai yang dilakukan oleh pengajar kepada pelajarnya selain dari poses belajar mengajar yang dilakukan sahari-hari. Tetapi sebenarnya, dalam proses ujian paper based didalamnya banyak hal yang menjadikan nilai yang dihasilkan tidak murni. Sebagai salah satu contoh permasalahan, kita ambil permasalahan Ujian CCIT paper based pada Perguruan Tinggi Raharja yang mengalami banyak kesulitan, diantaranya:

1. Soal ujian CCIT paper based yang mengacu pada soal ujian CCNA menyebabkan membuat soal ujian CCIT paper based sangat rumit. Soal CCIT yang mengacu dari CCNA computer based, maka setiap lembar soal untuk mahasiswa harus berbeda. Hal tersebut dapat memakan waktu yang tidak sedikit ditambah lagi dengan setiap lembar soal yang dimuat didalamnya terdapat ratusan soal bukan hanya 40 sampai 60 soal. 
2. Dalam mengerjakan ujian, mahasiswa pun mengalami kesulitan karena membutuhkan waktu yang sangat banyak disebabkan soal yang mereka kerjakan sangat banyak dan berbahasa Inggris (tidak seperti ujian mata kuliah yang lain). Untuk membaca, memahami, dan mengisi lembar jawaban membuat mahasiswa menjadi tidak optimal dalam mengisi soal-soal yang mereka hadapi. Waktu yang disediakan tidak sesuai dengan soal yang mereka kerjakan. Karena waktu yang diberikan adalah waktu yang biasa diberikan pada ujianujian biasanya.

3. Pada saat dosen memeriksa hasil ujian ini pun menjadi masalah yang cukup besar. Karena soal-soal yang berbeda untuk setiap mahasiswa maka dosen harus memeriksa sesuai dengan kunci jawaban yang benar (karena kunci jawabannya berbeda-beda) maka dosen harus sangat berhati-hati, kesalahan sedikit akan mengakibatkan hasil yang fatal dan akan merugikan mahasiswa. Hal tersebut dapat menghabiskan waktu yang banyak. Tidak cukup waktu sehari untuk memeriksa hasil ujian CCIT paper based karena memerlukan ketelitian yang sangat tinggi. Sedangkan, untuk meluangkan waktu yang banyak tersebut, dosen tidak dapat memenuhi karena kesibukan mengajar dan bekerja.

4. Selain hal-hal tersebut, ujian paper based pun bisa dikatakan tidak sesuai untuk ujian CCIT dikarenakan tidak sesuai dengan standarisasi CCNA. Ujian CCNA yang biasa dilakukan secara computer based sangat menggambarkan keefektifan suatu ujian Internasional.

Ujian computer based seharusnya dapat diimplementasikan pada Perguruan Tinggi Raharja karena selain dapat meminimalisir permasalahan-permasalahan di atas juga dapat menggambarkan bahwa Perguruan Tinggi Raharja dapat menjadi kampus berstandar Internasional dengan adanya sistem ujian computer based ini.

\section{PEMECAHAN MASALAH}

Ada sebuah konsep yang dipandang dapat mengatasi permasalahanpermasalahan ujian paper based. Konsep tersebut dikenal dengan nama ujian computer based. Cara kerjanya juga hampir menyerupai ujian Cisco CCNA dan TOEFL yaitu terdapat library soal-soal yang lebih dari 1000 soal agar pada saat mengerjakan ujian ini, soal yang muncul ke layar komputer pada setiap mahasiswa yang sedang melaksanakan ujian akibat sistem yang random menjadi tidak sama. Sebagai contoh, misalnya seorang mahasiswa Adan B sedang melaksanakan ujian computer based yang tempat dan waktunya sama, dan bersebelahan tetapi mereka tidak dapat bekerja sama karena setiap soal yang keluar ke layar mereka berbeda. 
Dan mereka dapat menyelesaikan soal dengan tenang karena mereka dapat mengetahui sisa waktu mereka masing - masing.

Ujian computer based itu sendiri adalah aplikasi komputer sebagai bagian integral dalam sistem ujian terhadap proses belajar dan mengajar yang bertujuan mempermudah siswa dalam proses ujian. Ujian berbasis komputer juga merupakan salah satu usulan yang dapat mengurangi tingkat kecurangan dalam proses ujian. [RLM09] Ujian yang berjalan melalui pola interaksi dua arah melalui terminal komputer mau pun multi arah yang diperluas melalui jaringan komputer (baik lokal maupun global) dan juga diperluas fungsinya melalui interface (antar muka) multimedia.

Untuk mengatasi semua permasalahan seperti yang telah dijelaskan, dan demi peningkatan mutu ujian dalam rangka meningkatkan kualitas, kredibilitas, dan akuntabilitas pada ujian [BSC11], maka pihak Perguruan Tinggi Raharja harus segera dapat menentukan sebuah kebijakan untuk mengubah sebuah sistem ujian paper based menjadi computer based dalam pelaksanaan ujian. Oleh karena itu, ujian computer based berstandar Internasional harus segera diimplementasikan untuk peningkatan mutu ujian itu sendiri. Selain mempermudah semua pihak yng ada didalamnya, hal ini juga dapat memecahkan permasalahan-permasalahan yang terdapat pada ujian paper based saat ini. Kelebihan-kelebihan dalam ujian computer based adalah:

1. Soal ujian hanya perlu diinput dalam sistem ujian computer based, tidak dipersulit dengan membuat lembar soal yang banyak dan berbeda-beda. Dosen juga dapat menambah serta mengupdate soal-soal yang akan dikerjakan oleh mahasiswa. Random soal sudah otomatis, maka kode soal dalam membuat soal yang berbeda sudah tidak diperlukan lagi.

2. Dosen juga dapat mengatur waktu yang dapat diberikan kepada mahasiswa ketika mahasiswa mengerjakan ujian, waktu yang diberikan tentu tidak sama dengan waktu ujian seperti biasanya (lebih banyak).

3. Dosen tidak perlu lagi harus meluangkan waktu yang banyak untuk memeriksa satu per satu jawaban mahasiswa sesuai dengan kode soal tetapi dalam ujian computer based, hasil ujian sesuai passing score yang dilakukan mahasiswa dapat diterima saat itu juga. Karena, sistem ujian computer based didalamnya terdapat tombol yang langsung menghitung hasil jawaban mahasiswa (past) failed).

4. Untuk mahasiswa dalam mengerjakan ujian computer based sangat dipermudah karena mahasiswa dapat melewati dulu soal yang dianggap sulit dan dapat kembali lagi ke soal yang belum terisi ketika soal sudah mencapai soal yang terakhir, hal itu dapat dilakukan dengan tombol next dan back 
yang ada pada sistem. Waktu yang menjadi kendala mahasiswa dalam ujian paper based tidak lagi menjadi masalah, karena dapat dilebihkan oleh dosen di dalam sistem tersebut sesuai dengan soal yang dikerjakan.

5. Ujian computer based juga akan menjadi aplikasi yang mendukung sebuah kampus sebagai kampus unggulan karena sistem ujian yang menjadi salah satu pilar mengadopsi standar Internasional.

\section{IMPLEMENTASI}

Implementasi dari penguraian di atas adalah dengan membuat sistem ujian computer based. Penanganan kekurangan-kekurangan dalam ujian paper based dapat diminimalisir menggunakan metode ujian computer based. Ujian computer based merupakan sistem yang harus dikembangkan oleh Perguruan Tinggi Raharja untuk tujuan sebagai sistem pelayanan ujian yang optimal bagi orang-orang yang terdapat didalamnya.

Hasil akhir yang ingin dicapai dari ujian computer based adalah ujian yang jumlah kesalahannya akan seminimal mungkin bahkan hingga mencapai 0\%.Karena itulah, untuk dapat mereduksi kesalahan dengan cara yang efektif, diterapkanlah metode ujian computer based ini.

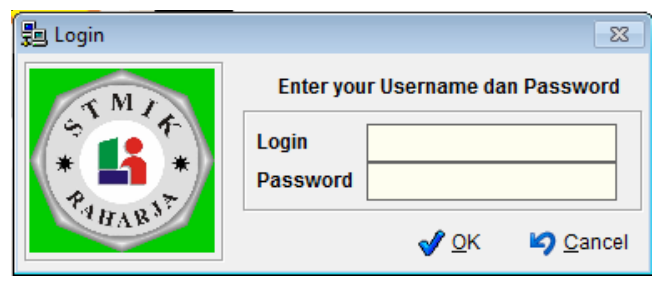

Gambar 1. Login admin dan mahasiswa

Pada Gambar 1 di atas merupakan tampilan awal untuk sistem ujian computer based.Dari halaman tersebut dapat diketahui apakah seseorang yang masuk sebagai mahasiswa untuk mengerjakan soal ujian atau sebagai admin yang dapat mengupdate sistem tersebut. Setiap mahasiswa dan admin yang masuk kedalam sistem ini sebelumnya akan di data agar dapat password untuk masuk dalam sistem ini.

Jika ternyata password yang dimasukkan adalah password admin, maka sistem ini akan segera memunculkan halaman untuk admin yang dapat mengupdate segala sesuatu yang berhubungan dengan sistem ini. Dapat dilihat paga gambar 2 


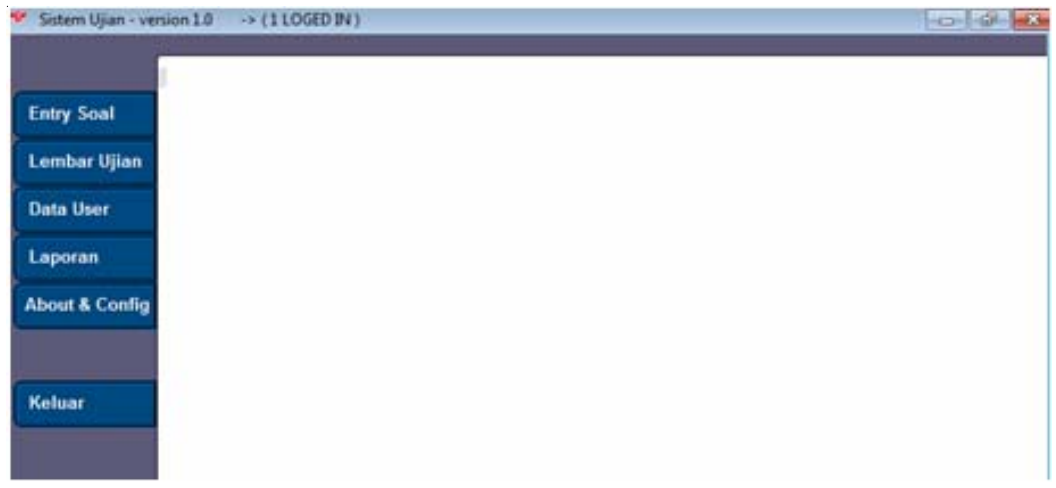

Gambar 2. Tampilan untuk admin

Tetapi lain halnya jika yang dimasukan adalah password mahasiswa, maka yang muncul adalah halaman soal beserta pilihan jawaban yang random. Berikut tampilannya.

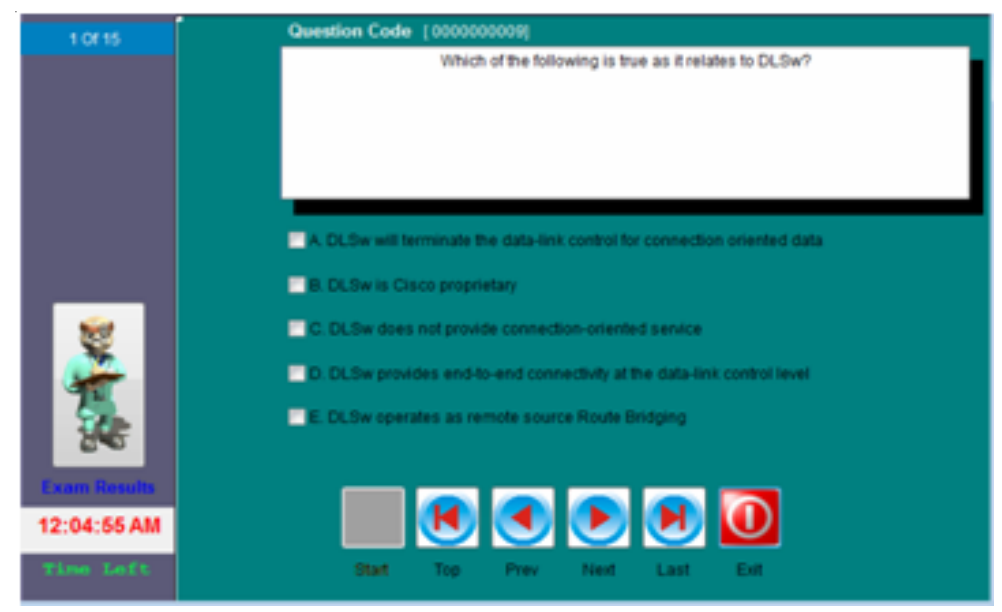

Gambar 3. Tampilan soal dan jawaban

Pada gambar 3 tersebut dihasilkan proses-proses ujian seperti kembali ke soal sebelumnya, lanjut ke soal berikutnya, keluar serta melihat hasil yang telah diperoleh dari jawaban yang telah diisi. Hasil dari ujian (Resume ujian) dapat dilihat pada gambar 4 . 


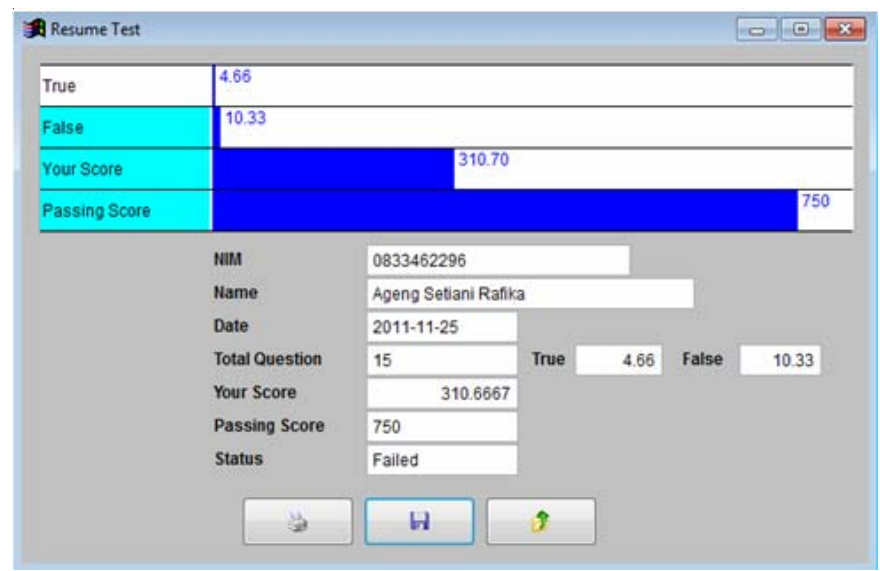

Gambar 4. Resume ujian

Ada satu kondisi lagi pada metode ujian computer based ini yaitu apabila pada saat ujian selesai dilakukan mahasiswa. Score dapat diperoleh secara langsung pada saat itu juga. Sesuai dengan pemecahan masalah yang telah diuraikan, hal ini dapat meringankan pekerjaan dosen.

\section{KESIMPULAN}

Ujian computer based merupakan salah satu bagian penting pada proses UTS dan UAS pada sebuah Perguruan Tinggi. Cara kerjanya yang meminimalisir segala kekurangan pada ujian paper based dan sangat membantu semua pihak yang terlibat dalam proses ujian. Ujian computer based sangat tepat apabila dapat digunakan secara umum untuk setiap ujian yang berlangsung. Hal ini sangat membantu karena selain menghemat waktu, tenaga, dan biaya, ujian computer based pun memberikan status yang jelas mengapa mahasiswa dapat lulus atau tidak lulus dari sebuah mata kuliah yang diikuti.

\section{DAFTAR PUSTAKA}

1. [BSC11] Basic Education Capacity - Trust Fund (2011).Kementrian Mengupayakan Peningkatan Mutu Ujian Nasional. Diakses dari: bectrustfund.wordpress.com/2011/09/23/kementerian-mengupayakan peningkatan-mutu-ujian-nasional/. 
2. [FJR09] Fajar (2009). Pengertian Ujian. Diakses pada tanggal 12 Desember 2011 dari: bangfajars.wordpress.com/2009/10/04/pengertian-ujian/

3. [KTM08] Kartimi (2008). Pengembangan Model pembelajaran Interaktif Berbasis Komputer Sebagai Wahana Pendidikan Siswa SLTP. Diakses pada tanggal 2 November 2011 dari: pkab.wordpress.com/2008/ 04/30/pengembangan-model-belajar-interaktif-berbasis-komputer/.

4. [RLM09] Rulam (2009). Pengertian Pembelajaran Berbantuan Komputer (Computer-Aided [Asisted] Instructions). Diakses pada tanggal 2 November 2011 dari: www.infodiknas .com/pengertian-pembelajaranberbantuan-komputer-computer--aided-asisted-instructions/.

5. [WKP11] Wikipedia (2011). Ujian Nasional. Diakses pada tanggal 10 November 2011 dari: id.wikipedia.org/wiki/Ujian_Nasional. 